\title{
Leadership and Conflict Resolution on the Production Line
}

\author{
Patricia I. Fusch \\ Walden University \\ Gene E. Fusch \\ Walden University
}

\begin{abstract}
Conflict between coworkers on the production line can be expensive as well as time consuming for companies. The business problem investigated in the study is the inability of supervisors on the production line to resolve conflict in nonunion companies, which, consequently, may lead to a drop in organizational productivity. Behaviors impacting shop floor productivity and performance were detected through miniethnographic and descriptive case study qualitative research methods through research of the production line leadership in a global company that manufactures kitchen and fireplace accessories. Results obtained from themes demonstrated that the production supervisor had some leader-member exchange leader characteristics including modeling behavior, individualized support of team members, resolving conflict in an appropriate manner that respected company culture and the existence of inner as well as outer circle members. Recommendations for future research included calling for additional empirical studies exploring the relationship between gender, diversity, and leader-member exchange effectiveness.
\end{abstract}

Keywords: leadership, conflict resolution, LMX, manufacturing, production supervisor

\section{Introduction}

Conflict resolution procedures in nonunion manufacturing companies have changed a great deal in the last 30 years and contemporary systems are inadequate at best (Abdel-Maksoud, Cerbioni, Ricceri, \& Velayutham, 2010). Such work appeared to have been abandoned in the latter half of the 20th century by scholarly studies concerning technology, sociotechnical relations, and management behavior (Hodson, 2008; Rowe, 1997). These types of studies are making a comeback as coworker relations are again receiving increased scrutiny in workplace studies (Humborstad, Nerstad, \& Dysvik, 2014); however, it has never rivaled research addressing group cohesion (Alexander, MacLaren, O'Gorman, \& Taheri, 2011; Hodson, 2008). Coworker conflict is perceived as being on the increase in the workplace, particularly in industrial manufacturing, as the workplace structures and relationships become more complicated, dense, fractured, and intense as flexible production and higher demands with fewer workers manifest (Brown \& May, 2012; Cole, Bedeian, \& Bruch, 2011; Dunn, 2012). Nonunion dispute resolution is poorly defined; moreover, there are no reliable numbers as to how many systems exist (Hodson, 2008). To be sure, participants discuss conflict resolution in a number of ways.

At the turn of the 21st century, nonunion dispute resolution in the United States was handled by government entities that focused on addressing employee civil rights violations, whereas employers were concerned with the effects on the workplace such as loss of productivity, sabotage, and theft (Hodson, 2008; Rowe, 1997). For the organization, these may include reduced employee performance, 
workplace violence, increasing absenteeism, job turnover, career burnout, and job dissatisfaction (Harrell, 2011) resulting from hostility, sabotage, interpersonal aggression, theft, work avoidance, and threats (Bannon, Ford, \& Meltzer, 2010). The decline in union shops and their formalized grievance procedures were leaving a void in effective conflict resolution procedures (Hodson, 2008; Rowe, 1997).

Employees cannot effectively do their jobs if they are unhappy or stressed because of conflicts on the production line and, therefore, job satisfaction is directly related to the attainment of organizational goals and organizational effectiveness (Ariani, 2012; Ayoko \& Callan, 2010; Cheung \& Wu, 2012; Fisk \& Friesen, 2012; Streb \& Gellert, 2011; Yuan, 2010). Effective leadership is important on the production line to resolve conflict that may impact productivity, particularly in nonunion shops without formal grievance procedures in place (Voegtlin, Patzer, \& Scherer, 2012; Yuan, 2010). The most effective leaders understand that conflict resolution begins with knowing what conflict is, how to manage it, and when to do so (Voegtlin et al., 2012; Yuan, 2010). Leaders as mediators have a significant impact on response to change in their organizations through their communication and conflict styles (Klein, Knight, Ziegert, Lim, \& Saltz 2011). To be sure, leaders set an example for others when resolving conflict in the workplace (Streb \& Gellert, 2011; Voegtlin et al., 2012; Yuan, 2010).

\section{Theoretical Framework}

The theoretical framework for the study fell under the broad conceptual and theoretical framework of leader-member exchange (LMX) theory. As applied to leadership theory, the concept is based on motivating followers by providing rewards through reinforcement (Jackson \& Johnson, 2012; Volmer, Spurk, \& Niessen, 2011). Reinforcement theory can be summarized by Thorndike's 1911 law of effect, which states that the likelihood of a behavior being repeated is dependent on the consequence of a behavior (Thorndike, 1898).

\section{Literature Review}

There are three types of conflict in organizations: task, relationship, and process (Klein et al., 2011). Task conflict refers to the conflict arising from the content and goals of the work (Ayoko \& Callan, 2010; de Wit, Greer, \& Jehn, 2011). Relationship conflict is that which concerns interpersonal relationships within the organization (Ayoko \& Callan, 2010; de Wit et al., 2011). Process conflict refers to how the work gets done (de Wit et al., 2011; Streb \& Gellert, 2011).

Conflict appears to be inevitable and may define the future of relationships between coworkers on the production line (Douglas, 2012; Kotlyar, Karakowski, \& Ng, 2011). Leaders view conflict as an indication that something needs to be addressed (Medler-Liraz \& Kark, 2012). Leaders have selfidentified conflict management as their greatest concern and weakness when addressing difficult subordinates (Trudel \& Reio, 2011). Leaders are key actors in handling conflict management and resolution within the organization through power and political leadership skills, for the success of a company may be dependent upon its people (Kacmar, Bachrach, Harris, \& Noble, 2012). Conflict between coworkers is expensive as well as time consuming for companies (Behar, Mannix, Peterson, \& Trochim, 2011).

Conflict resolution theory began in the 1950s during the Cold War and addressed dispute resolutions between nations (Nowak, Deutsch, Bartkowski, \& Solomon, 2010). Workplace conflict resolution theory began with Morton Deutsch, who is considered by many to be the founder of modern conflict resolution theory and practice (Nowak et al., 2010). He was heavily influenced by Kurt Lewin, the 
father of social psychology, and has spanned the fields of cooperation and competition, intergroup relations, conflict resolution, social conformity, and the social psychology of justice (Nowak et al., 2010). Building upon Deutsch's work, Karen Jehn's work involved negotiation and conflict management (Bezrukova, Thatcher, Jehn, \& Spell, 2011) and examined intragroup conflict, group composition and lying in organizations, as well as differences in perception within workgroups and their impact on organizational goals (Bezrukova et al., 2011).

Moreover, conflict resolution theory has expanded to include a number of theoretical models (Spector, 2011; Tabassi \& Bahar, 2010) including the Blake and Mouton managerial grid model (Tabassi \& Bahar, 2010). Also, the Thomas-Kilmann conflict mode instrument (Thomas, Thomas, \& Schaubhut, 2008) has been used. In addition, the self-published Kraybill Conflict Style Inventory, as developed by Dr. Ronald S. Kraybill in the 1980s (Kraybill, 2011), is also used.

\section{Sensemaking}

Conflict resolution involves sensemaking, where individuals communicate and make sense together, which is framed by a common culture (Abolafia, 2010; Conroy \& O'Leary-Kelly, 2014; Ivanova \& Torkkli, 2013). When transformation change happens, the framing as well as the communication practices change; hence, the culture adapts (Colville, Brown, \& Pye, 2011). Some adoptions encourage innovation and some discourage deviation from the way things have always been done and how communication has been conducted (Thurlow \& Mills, 2009, Weick, 2011). Forgiveness after a conflict is important to restore harmony between participants (Goldman \& Wade, 2012; Green, DeCourville, \& Sadava, 2012). Moreover, in addition to letting go of anger and moving forward, victims are more likely to forgive their transgressors in order to preserve a long-term relationship and establish a new imagined future between parties (Goldman \& Wade, 2012; Green et al., 2012) to let go of past hurt and anger and move forward to reconciliation (Goldman \& Wade, 2012; Green et al., 2012).

\section{Leadership}

There are a number of leadership theories as well as definitions of leadership (Odumeru \& Ifeanyi, 2013) which is indicative of its elusive and complex nature. There is more divergence than convergence (Odumeru \& Ifeanyi, 2013). Leadership is where an individual influences a group to achieve a common objective (Northouse, 2015). Organizational leadership involves both the leaders and the followers (Fisk \& Friesen, 2012). It is an interactive and transactional event or events whereby each is influenced by the other to achieve a common goal (Chaudhry \& Javed, 2012). Research in the area of leadership style focuses on two kinds of behavior: task and relationship (da Cruz, Nunes, \& Pinheiro, 2011). Task behaviors are those which direct efforts towards goal and objective accomplishment, while relationship behaviors focus effort on aiding subordinates to feel comfortable with themselves and others (da Cruz et al., 2011; Northouse, 2015). It is the successful blending and coordination of the two that marks the effective organizational leader (da Cruz et al., 2011).

\section{Great Man/Trait Theory}

The trait approach to the study of leadership behaviors evolved out of the great man theories in the late 1940s and has recently gained renewed interest from researchers (DeRue, Nahrgang, Wellman, \& Humphrey, 2011; Hoffman, Woehr, Maldagen-Youngjohn, \& Lyons, 2011). Trait leadership is a pattern of characteristics that determine consistent effectiveness across a spectrum of situations (Antonakis, Day, \& Schyns, 2012). Early theorists posited that these characteristics were inherent 
(Antonakis et al., 2012). Contemporary researchers continually demonstrate that the idea that one great man or great woman can decide the fate of an organization is highly unlikely (Hoffman et al., 2011). Trait leadership theorists use a more straightforward approach that focuses on the leader's abilities and skills set rather than the perception of followers or the particulars of circumstance (DeRue et al., 2011; Northouse, 2015).

\section{Contingency Theory}

Contingency theory is a leader-match perspective of effective leadership that is contingent on matching a leader's style to the right situation (Northouse, 2015). The theory was first described by F. E. Fielder in 1964 and then elaborated on in 1987 with J. E. Garcia, then further developed through the study of various organizations, predominantly military (see da Cruz et al., 2011). Fiedler studied leadership styles, both good and bad, and analyzed whether these types of styles were effective and in what types of situations and contexts (da Cruz et al., 2011). He developed the concept of the least preferred coworker (Northouse, 2015).

\section{Transformational Leadership Theory}

The term transformational leadership was first used in Burn's 1978 seminal work about leadership (see Hargis, Watt, \& Piotrowski, 2011). In his work, he coined two new concepts-transactional leadership and transformational leadership_-in an attempt to explain leader-follower relationships in the political world (Hargis et al., 2011). The concept was then adapted by the business world to explain how such relationships contributed to group outcomes in an organizational setting (Hargis et al., 2011).

It was followed by the 1985 Bass model of transformational leadership based on four dimensions that are interconnected (see Zhu, Sosik, Riggio, \& Yang, 2012), which include (a) idealized influence or charisma, (b) inspirational motivation, (c) intellectual motivation, and (d) individualized consideration (Judge, Piccolo, \& Kosalka, 2009; Kotlyar et al., 2011). The primary contention of the concept is that the leader provides the follower with more than just a job; he or she provides a sense of identity as well as community through an inspiring mission by idealized influence, intellectual stimulation, and individual consideration (Zhu et al., 2012). Finally, Bass noted that leaders can be transformational as well as transactional at the same time (see Kotlyar et al., 2011).

\section{Emotional Intelligence Theory}

The term emotional intelligence was derived from Thorndike's early 20th-century work on social intelligence, then gained ground in popular culture in the early 1990s with Goleman's 1995 seminal work, Emotional Intelligence (see Cheng, Huang, Lee, Xiaopeng, 2012). The concept addresses environmental triggers in the workplace and how to best identify them in order to deal with them (Cheng et al., 2012). Emotions are perceived to be critical to the effectiveness of the organization and essential to organizational behavior (Cheng et al., 2012). Components of emotional intelligence are self-motivation, persistence despite setbacks and frustrations, impulse control, delay of gratification, self-mood regulation, stress control, empathy, and hope. The emotional makeup of group teams within organizations is critical to the success of the company (Chang, Sy, \& Choi, 2012; Cheng et al., 2012; Prilipko, Antelo, \& Henderson, 2011). The ability to harmonize in the workplace is the skill to be able to take advantage of the talents of group members' ability to leverage intellectual capital (Chang et al., 2012). The emotionally intelligent group and its members best utilize human capital to the task at hand, thereby contributing to the efficient running of the organization (Chang et al., 2012). Leadership is not about giving orders; it is the art of motivating followers to work toward a common goal (Chang et al., 2012). 


\section{Transactional Leadership Theory}

The antecedents of transformational leadership theory arose out of Vroom's 1964 expectancy theory as well as Luthans and Kreitner's 1985 reinforcement theory (see Luthans, Rhee, Luthans, \& Avey, 2008). Homans and Adams are generally credited with the development of exchange or equity group theory in that individuals seek to maintain equity between what they give versus what they obtain in an exchange (see Shore \& Strauss, 2012).

The term transactional leadership was coined by Burn's in his seminal work about leadership (see Hargis et al., 2011). Transactional leadership is a process between a leader and followers and occurs in groups, both large and small (Hargis et al., 2011). It is a disciplined practice that can be learned through training and education, through self-awareness and self-management, and by managing relationships (Douglas, 2012). Transactional leadership has been described as a give and take process whereby leaders reward or punish followers to influence and motivate follower behavior (Douglas, 2012). Also known as managerial leadership, transactional leaders do not look to change the future, but rather to maintain the status quo (Douglas, 2012) and are particularly effective in crisis situations where instantaneous feedback is imperative to make real time decisions and mobilize a quick response. In the context of Maslow's 1943 hierarchy of needs, transactional leaders address the basic levels of needs satisfaction and are particularly effective when addressing specific work tasks. Transactional leaders accept the existing culture of the organization and are action oriented (Douglas, 2012).

Transactional leadership concepts were further adapted from the exchange-based theories of the 1980s (Hargis et al., 2011). Transactional leadership contains two motivational factors known as contingent reward/constructive transactions as well as management-by-exception (Antonakis et al., 2012). Contingent reward leaders recompense followers who meet agreed-upon performance standards (Antonakis et al., 2012). Leaders who use management by exception, also known as the higher order of transactional leadership, are of two types: active management by exception and passive management by exception (Antonakis et al., 2012), where leaders use discipline to change follower behavior (Hargis et al., 2011). Active management by exception is also known as active corrective transactions, whereby the leader is constantly and consistently monitoring follower behavior (Antonakis et al., 2012). Passive management by exception is commonly referred to as passive corrective transactions, whereby leaders use discipline after a transgression when a mistake or error is made by a follower (Antonakis et al., 2012).

Finally, a form of leadership that is neither transformational nor transactional is laissez-faire leadership or absence of leadership (Edwards \& Gill, 2012). Laissez-faire leaders avoid making decisions through hesitancy or deliberate action and are frequently absent when decisions need to be made (Chaudhry \& Javed, 2012). It can be argued that the type of leader should not be included in any discussion regarding transformational or transactional leadership; however, laissez-faire leadership is often researched alongside other leadership models to determine leadership style effectiveness (Chaudhry \& Javed, 2012; Judge \& Piccolo, 2004).

\section{Leader-Member Exchange Theory}

LMX theory focuses on one-to-one exchange-based relationships between a leader and a follower and the resulting relationship's unique characteristics (Dadhich \& Bhal, 2008; Dulebohn, Bommer, Liden, Brouer, \& Ferris, 2012; Kuvaas, Buch, Dysvik, \& Harerem, 2012). The positive relationship between leader and production worker may then have a positive impact on the attainment of an organization's goals (Ariani, 2012). Also known as vertical dyad linkage theory, LMX is concerned 
with increasing organizational productivity outcomes through the fostering of positive relationships and communication between a leader and follower (Dadhich \& Bhal, 2008). Followers can be divided between ingroup members with close relationships with the leader as well as outgroup members who have distant relationships with the group leader (Pelletier, 2011).

The LMX process begins once a member joins the group and consists of three steps: role taking, role making, and routinization (Le Blanc \& Gonzalez-Roma, 2012). Members join a group where the leader assesses characteristics to decide whether the member will be an inner circle participant or one of the outgroup followers (Ariani, 2012). Secondly, the leader and member enter a series of tacit negotiations concerning the member's position within the group, as well as potential rewards for loyalty, dedication, and hard work (Le Blanc \& Gonzalez-Roma, 2012). Trust is a key component of the assessment, as any form of perceived betrayal will result in the member's banishment to the out group (Ariani, 2012). The final stage of the LMX process is the ongoing maintenance of the leader follower relationship (Volmer et al., 2011). The relationship will usually remain consistent at the point barring disruptions such as changes in workload or financial feasibility challenges (Walumbwa, Peterson, Avolio, \& Hartnell, 2012).

LMX appears to be understood as a contractual agreement (Dadhich \& Bahl, 2008) and can mitigate toxic leadership in the workplace as well as promote high performance productivity in teams (Pelletier, 2011). One of the critiques of LMX is the propensity for abusive leaders to distort leadermember relationships to the point of abuse of subordinates (Ding, Tian, Yang, \& Gong, 2012). Abusive leadership is correlated with decreased worker effort and organizational citizenship behaviors (Harris, Harvey, \& Kacmar, 2011). Low-quality LMX relationships result in fewer job rewards and satisfaction and may enhance victimization of low-power subordinates (Volmer et al., 2011).

\section{Method}

\section{Study Participants}

Pacific Manufacturing is a pseudonym for a mid-sized manufacturing company in northwestern Washington State that has been in business for 4 decades. The company's mission is to manufacture and distribute cooking racks, pot racks, cooking accessories, kitchen furniture, fireplace log racks, and many other products for retail sales for large to mid-sized companies. Many of the company's employees have been working at Pacific for 25 years; some have been working for the company for less than 5 years. Pacific was expected to meet or exceed $\$ 2.2$ million in revenue for 2013 , 2014, and 2015.

Participants consisted of 11 production line employees that include workers and supervisors. The selection of the participants came about through the ethnographic fieldwork techniques of direct observation to ascertain the key members of each production line (Onwuegbuzie, Leech, \& Collins, 2010). Bernard (2012) stated that the number of interviews needed for a qualitative study to attain data saturation was a number he could not quantify, but that the researcher takes what he can get. However, it can be stated that data saturation was reached when there was enough information to replicate the study (Anderson, 2010; Walker, 2012), when the ability to obtain additional new information has been attained (Guest, Bunce, \& Johnson, 2006), and when further coding was no longer feasible (Guest et al., 2006). Participants in the ethnographic study were nine men and two women ranging in age from 18 to 65 years. Only one participant had a college degree. Tenure on the job site ranged from 5 months to 29 years of employment. All participants were White, with the lone exception of one worker of mixed-race background. All participants were local residents, which is of 
particular importance, as the research site was located in a small town with little potential of employment elsewhere that paid a living wage.

\section{Research Method and Design}

In order to interpret what influences first-level supervisor conflict resolution skills on the production line in nonunion shops, a miniethnographic descriptive case study research design was used (Denzin, 2008; Marshall \& Rossman, 2011). The behaviors impacting shop floor productivity and performance were detected through miniethnographic and descriptive case study qualitative research methods by studying first level production leadership in a mid-sized global manufacturing company in the Pacific Northwest to identify theory that explains the phenomenon. The sampling method used was census sampling. The qualitative research methods included conducting fieldwork (Dennis, 2010; Jackson, 1990) with direct observation (Gordon, 2011; Marshall \& Rossman, 2011), a focus group (Doody, Slevin, \& Taggart, 2013), a reflective journal (Sangasubana, 2011), review of company documents/literature related to production outcomes as well as previous conflict incidents on the production line (Yin, 2015), and unstructured interviews (Bernard, 2012; Rubin \& Rubin, 2012) for triangulation (cross-examination) purposes (Bekhet, \& Zauszniewski, 2012; Denzin, 2012; Fusch, 2008).

The research questions consisted of what was happening, how the participants understood appropriate conflict resolution, and the meaning participants attributed to conflict resolution. The overarching research question for the study was, "How do first line production supervisors resolve conflict on the production line?" The question chosen was to identify the behaviors that a production line supervisor demonstrated during a conflict resolution and how these behaviors fostered shop floor productivity and performance as related to LMX theory.

Furthermore, only one of the four following questions drew information from a supervisor's perspective only (Q4). The first two questions elicit the perspective of someone witnessing the conflict (the researcher, production line workers, the supervisor, or more). The method drives research through openness, which is about receiving multiple perspectives about the meaning of truth in situations where the observer cannot be separated from the phenomenon (Dibley, 2011). The concept is found in interpretive theory, wherein the researcher operates thorough a belief in the multiplicity of peoples, cultures, and means of knowing and understanding (Manning \& Kunkel, 2014). Finally, for Q3, the primary focus was the production worker's perspective.

\section{Results}

\section{Finding 1: Resolving Task Conflict}

The study findings revealed that first line production supervisors resolved task/process conflict on the production line by first placing the blame on others for mistakes made. In addition, the production supervisor escalated major task/process conflicts to the owner for intervention where all relevant participants engaged in a resolution. Moreover, the supervisor's approach differed when engaging men or women and further differentiated in regards to diversity, tenure, age, and education levels of subordinates. Finally, the production supervisor was proactive about attaining materials that production workers needed in a timely manner. 


\section{Finding 2: Resolving Relationship Conflict}

The study findings revealed that first line production supervisors resolved relationship conflict by allowing workers to vent, taking participants aside to hear perspectives, telling participants to stop the behavior, making a joke to lower tensions, and/or reporting major conflicts to the owner to resolve. Moreover, the supervisor's approach differed when engaging men or women. In addition, the supervisor's approach differed in regards to diversity, tenure, age, and education levels of subordinates. Finally, workers resolved many conflicts between themselves that never reached the level of supervisory intervention.

\section{Finding 3: Meaning for Production Workers}

The study findings revealed that the kinds of meaning that production workers gave to conflict resolution were that sometimes they were taken seriously and sometimes not. This resulted in their feelings of helplessness when they were forced to take the blame for something that was not their fault. When taken seriously, workers stated that their concerns heard and validated, as well as addressed, and the perpetrator was punished by appealing to a higher authority (the owner).

\section{Finding 4: Meaning for Supervisors}

The study findings revealed two kinds of meaning that supervisors give to conflict resolution. The first was that victims' concerns were heard as well as respected. The second was that the work of the company could resume as the conflict was now resolved.

\section{Discussion}

\section{Major Themes}

The production supervisor demonstrated the following LMX characteristics: providing an appropriate model; expecting high performance; providing individualized support; demonstrating individual engagement based on gender, age, education, tenure at the job, and diversity when resolving conflict; encouraging the existence of an inner circle of confidents; and abusing LMX relationships. The supervisor is a transactional leader within the LMX theoretical framework (Dadhich \& Bhal, 2008). The result was expected given the theoretical framework applied (Douglas, 2012). The meaning of conflict resolution is primarily the maintenance of the status quo rather than change (Rockstuhl, Dulebohn, Ang, \& Shore, 2012). Status quo is very important to the workers; everyone understands the parameters/boundaries and knows how to act and how others should act (Rockstuhl et al., 2012) so that everyone can get back to work. It is important to preserve the workplace culture and norms within which the employees work, as established in LMX theory (Douglas, 2012). Workers can adapt to changes if need be; however, it must be managed within the established cultural framework of the workplace (Sabir, Sohail, \& Khan, 2011). A change is tested to see if it fits and discarded quickly if not; however, workers adopted a change somewhat reluctantly if required by an authority figure (Ding et al., 2012).

Unresolved conflict is expensive for companies and can result in loss of time, money, and resources (Kirby, 2011). As task conflicts rise, employee performance decreases (Anwar, Maitlo, Soomro, \& Shaikh, 2012). Moreover, task conflict reduces social capital and group coordination in the workplace (Anwar et al., 2010); however, task conflict appears to be mitigated by team members' trust in their supervisor (de Wit et al., 2011). In addition, effective leaders can encourage member commitment through the suppression of team conflict (Kotlyar et al., 2011). Also, task conflict is particularly disruptive regarding routine tasks; therefore, LMX supervisors must actively engage in resolving it 
(Lehmann-Willenbrock, Grohmann, \& Kauffeld, 2011) to remedy and mitigate further cost and expense (Olaniran, 2010; Williams, 2011) through supervisory skills of mediation, confrontation, and communication (Aryee, Walumbwa, Zhou, \& Chad, 2012). Conflict resolution involves sensemaking, in that individuals communicate and make sense together framed by a common culture (Colville et al., 2011). An LMX leader's individualized support of subordinates suggests that enabling the victim in sensemaking may expedite conflict resolution (Sadeghi \& Pihie, 2012). LMX theory is a process that demonstrates how leaders sustain and maintain relationships in groups through unstated yet understood emotional exchange agreements with group members (Dadhich \& Bhal, 2008; Kuvaas et al., 2012). The final stage of the LMX process illustrates the on-going maintenance of the leaderfollower relationship (Volmer et al., 2011). The relationship will usually remain consistent at the point barring disruptions such as changes in workload or financial feasibility challenges (Walumbwa et al., 2012).

Workers attending the focus group session noted that the supervisor had a wide scope of knowledge of the company as evidenced by their unanimous agreement that the supervisor had a lot of knowledge, stating that he has a lot of parts of the production process that he tracks in his head. It was confirmed by three workers during a conversation, the focus group session results where participants unanimously agreed that the supervisor had a lot on his plate, as well as an interview with the supervisor. What production subordinates are referring to here is tacit knowledge (Chang, Lu, Kung, \& Ueda, 2014). As the workplace becomes increasingly complex and decisions need to be made in shorter time-periods with less practical knowledge than before, the ability to implement tacit knowledge grows (Chang et al., 2014). Tacit knowledge is a subjective individualized body of knowledge and practical knowhow that has come about through tenure on a job (Chang et al., 2014). It may be labeled as intuition, which is the ability to implement a solution where practical knowledge is combined with logical thought processes that recognize patterns, or what is known as gut instinct (Chang et al., 2014). It is difficult to define, but one knows when one sees it, a colloquial expression made popular by Supreme Court Justice Potter referencing pornography (Jacobellis $v$. Ohio, 1964). Moreover, intuition is difficult to articulate and capture; the type of knowledge is also difficult to disseminate resulting in organizations who cannot easily replace knowledgeable managers (Chang et al., 2014) due to a lack of formalized mentoring programs such as the journeyman/apprentice relationship.

\section{Minor Themes}

The autocratic owner demonstrated transformational behaviors in a time of crisis. Within the depth of the current economic crisis, the company owner called a meeting of all employees to address the downturn of the economy and the result on production and sales as well as discussing any potential layoffs. Transformational leaders use vision to inspire employees to complete or increase the work of production (Rupprecht, Waldrop, \& Grawitch, 2013). They influence others' self-efficacy and wellbeing (Rupprecht et al., 2013). Callahan (2008), in a review of Goleman and others, listed the four Cs of emotion-context, challenges, communication, and community-which are the underlying causes of emotion and the social lubricant between people. One can identify the emotional trigger and then choose the method of addressing the emotion particularly when one's job is at stake (Callahan, 2008; Cheng et al., 2012). Organizational leaders adjust to a changing environment through training, leadership competencies, and strategy (Callahan, 2008; Cheng et al., 2012).

\section{Unexpected Themes}

The following themes emerged from the data that were not expected: the workers' anger over their poor treatment by the supervisor despite a long history of his personal relationships with them, the 
owner's autocratic leadership style that became collaborative at a time of crisis, and the accepted emerging leadership style of the female workers in a male-dominated workplace. Another unexpected theme was the prevalence of production silos. One final unexpected theme was the compassionate outlook of the autocratic owner towards an employee struggling with a substance abuse problem.

\section{Women Leadership at the Site}

One unexpected outcome concerned the acceptance of emerging leadership style of the women workers in a men-dominated workplace. The theme was identified by observing that the woman packing lead called for a solution to a relationship conflict with a man production worker over discriminatory behavior resulting in a hostile work environment. A woman supervisor initially resolved the conflict by confronting the transgressor. The relationship conflict incident resulted in a policy memo to address consequences. In our interview with the lead, we found that the conflict was resolved to the women worker's satisfaction.

In LMX theory, relational demography is an important consideration when researching dyads (Avery, Volpone, McKay, King, \& Wilson, 2012). Relational demography is the demographic differences between participants in a dyad, such as gender (Avery et al., 2012), that have an impact addressing effective communication between participants. Research addressing Helgeson's web of inclusion found that gender does not seem to have any impact on dyads (see Martin, 2009), as the web of inclusion includes all. Most researchers address LMX controls for gender; therefore, there is little empirical research that links gender with either positive or negative (Cote, Lopes, Salovey, \& Miners, 2010) LMX behaviors.

\section{Production Silos}

Another unexpected theme was the prevalence of production silos. Production at the research site is an amalgamation of classic assembly line production and what the researchers called production silos. The amalgamation makes for some degree of confusion and chaos. In other words, production is not as smooth a flow as it could be as evidenced by direct observation during the data collection phase of the study.

A silo is a system that is incapable of working with others by the inability to exchange information with other systems (Gil-Garcia, 2012). Worker focus is inward driven and their communication is vertical to higher authority rather than horizontal to like systems (Gil-Garcia, 2012). Negative aspects include lack of coordination and communication as well as the absence or little demonstration of interoperability with the result of limiting or severely hampering productivity (GilGarcia, 2012). Cohesiveness is important for teamwork function and positive attitudes towards the organization (Kotlyar et al., 2011). In addition, effective, cohesive teamwork is positively related to intelligence and skills, reducing conflict, increasing trust, and performance commitment (Kotlyar et al., 2011). Understandably, job context is a concern and a production silo may be more difficult to address; however, it necessarily indicates a deeper commitment from the production supervisor to promote coordination (Farh \& Seo, 2012).

\section{Limitations and Recommendations for Future Research}

The study findings bring into consideration a number of directions for further research. Keeping in mind that depth of information increases the potential of transferability for qualitative research (Aastrup \& Halldorsson, 2013), further research may be necessary to obtain more in-depth results than those illustrated by the study. To be sure, the application of triangulation (multiple sources of data) will go a long way towards enhancing the reliability of results (Aastrup \& Halldorsson, 2013). 


\section{Size of the Group}

The research design included a mid-sized global company that employs approximately 11 production line workers. There were two first level supervisors on the shop floor. The size of the optimum group for LMX is a concept debated amongst scholars that addresses Fayol's theory of span of control (see Pelletier, 2011).

\section{Timeframe}

In addition to the usual concerns and limitations with ethnography as a research method, the miniethnography (also known as the micro ethnography) has specific concerns as to timeframe (Alfonso, Nickelson, \& Cohen, 2012). The research study design had both researcher-originated limitations and site-produced limitation. The research was self-funded, and it restricted the finances as well as the amount of time to pursue the study. Given these limitations, we were limited to a 4week time period. Future research should address time limitations by expanding the research design to at least 1 year in the field.

\section{Sensemaking}

Sensemaking in reconciliation is an ongoing process with no end resolution in sight. Reconciliation is dependent on restoring a victim's feelings of justice (Bisel \& Arterburn, 2012). Moreover, reconciliation is not always an effective resolution nor does it reflect true discontent with the status quo since it depends on the exercise of voice that is not always apparent (Bisel \& Arterburn, 2012). Future research would need to take into account that reconciliation may be never ending.

\section{Diversity in Groups}

Diversity in teams and its impact on conflict resolution is a topic of increasing interest in research. There are few if any consistent findings; outcomes vary from study to study (Klein et al., 2011). Future research would need to take into account that preliminary findings as to the connections between diversity and conflict resolution are tenuous at best.

\section{Production Silos}

A further limitation to the study and potential for future research addresses the prevalence of production silos at the research site. Admittedly, transformational leaders have a greater ability to overcome barriers through attending to the emotional needs of their members (Chang et al., 2012). Future research addressing these same abilities in transactional leaders is needed because interactions between workers tend to be task oriented. Researchers should also address the transactional leader's role as monitor in order to mitigate shortcomings (Zimmerman, 2011).

\section{Conclusions}

In the January 1849 edition of Les Guepes, a satirical journal, the editor, Jean Baptiste Alphonse Karr, wrote the famous line "plus ca change, plus c'est la meme," which, when translated into English, states that the more things change, the more they stay the same (see Bhargava, 2013). While Karr wrote about daily life and politics in France of the mid-19th century, his famous quote could just as easily referenced organizations of the 21st century. Indeed, organizations today are changing rapidly due to technology, globalization, and cutting-edge production, subsequently morphing into new structures and workflow processes (Narasimhan, Krull, \& Nahm, 2012; Voegtlin et al., 2012). Yet, the core of organizational composition remains in the human resource realm, where needs and wants remain the same as they have always been, for meaningful, creative work as well as recognition and reward in the workplace, for one factor contributing to company success is its people. 
Effective leaders know when to resolve conflict in an effective manner to impact positive performance in the workplace (Ahmad, 2011; Alexander et al., 2011). Leaders provide direction to facilitate the processes that enable the workers to get the work of the organization done by providing role models for subordinates to emulate as well as correctly defining a problem from start to finish (Prilipko et al., 2011). During a conflict, an effective leader should be flexible in order to implement a creative solution that facilitates an appropriate response that demonstrates the correct use of focus and resources to return the company to business as usual.

\section{References}

Aastrup, J., \& Halldorsson, A. (2013). Quality criteria for qualitative inquiries in logistics. European Journal of Operational Research, 144, 321-332. doi:10.1016/S0377-2217(02)00397-1

Abdel-Maksoud, A., Cerbioni, F., Ricceri, F., \& Velayutham, S. (2010). Employee morale, nonfinancial performance measures, deployment of innovative managerial practices, and shopfloor involvement in Italian manufacturing firms. The British Accounting Review, 42, 36-55. doi:10.1016/j.bar.2010.01.002

Abolafia, M. (2010). Narrative construction as sensemaking. Organization Studies, 31, 349-367. doi:10.1177/0170840609357380

Ahmad, K. Z. (2011). Warmth in groups and satisfaction with supervision. International Journal of Business and Management, 6, 129-136. doi:10.5539/ijbm.v6np129

Alexander, M., MacLaren, A., O’Gorman, K., \& Taheri, B. (2011). "He just didn't seem to understand the banter": Bullying or simply establishing social cohesion? Tourism Management, 33 , 1245-1255. doi:10.1016/j.tourman.2011.11.001

Alfonso, M., Nickelson, L., \& Cohen, D. (2012). Farmers' markets in rural communities: A case study. American Journal of Health Education, 43, 143-151. Retrieved from http://www.aahperd.org/aahe/publications/ajhe/

Anderson, C. (2010). Presenting and evaluating qualitative research. American Journal of Pharmaceutical Education, 74, 4-7. Retrieved from http://www.ajpe.org/

Antonakis, J., Day, D. V., \& Schyns, B. (2012). Leadership and individual differences: At the cusp of a renaissance. The Leadership Quarterly, 23, 643-650. doi:10.1016/j.leaqua.2012.05.002

Anwar, N., Maitlo, Q., Soomro, M., \& Shaikh, G. (2012). Task conflicts and its relationship with employees' performance. Interdisciplinary Journal of Contemporary Research in Business, 3, 1338-1343. Retrieved from http://www.ijcrb.webs.com/

Ariani, D. W. (2012). Leader-member exchanges as a mediator of the effect of job satisfaction on affective organizational commitment: An empirical test. International Journal of Management, 29, 46-56. Retrieved from http://www.internationaljournalofmanagement.co.uk

Aryee, S., Walumbwa, F. O., Zhou, Q., \& Chad, A. (2012). Transformational leadership, innovative behavior, and task performance: Test of mediation and moderation processes. Human Performance, 25, 1-25. doi:10.1080/08959285.2011.631648

Avery, D., Volpone, S., McKay, P., King, E., \& Wilson, D. (2012). Is relational demography relative? How employment status influences effects of supervisor-subordinate demographic similarity. Journal of Business \& Psychology, 27, 83-98. doi:10.1007/s10869-011-9230-9

Ayoko, O. B., \& Callan, V. J. (2010). Teams' reactions to conflict and teams' task and social outcomes: The moderating role of transformational and emotional leadership. European Management Journal, 28, 220-235. doi:10.1016/j/emj.2009.07.001 
Bannon, S., Ford, K., \& Meltzer, L. (2010, July). How to instill a strong ethical culture. The CPA Journal, 25, 56-58. Retrieved from http://www.cpajournal.com

Behar, K. J., Mannix, E. A., Peterson, R. S., \& Trochim, W. M. (2011). Conflict in small groups: The meaning and consequences of process conflict. Small Groups Research, 42, 127-177. doi:10.1177/1046496410389194

Bekhet, A. K., \& Zauszniewski, J. A. (2012). Methodological triangulation: An approach to understanding data. Nurse Researcher, 20, 40-43. Retrieved from http://www.nursingstandard.co.uk

Bernard, R. H. (2012). Social research methods: Qualitative and quantitative approaches (2nd ed.). Thousand Oaks, CA: Sage.

Bezrukova, K., Thatcher, S. M. B., Jehn, K. A., \& Spell, C. S. (2011). The effects of alignments: Examining group faultlines, organizational cultures, and performance. Journal of Applied Psychology, 97, 77-92. doi:10.1037/a0023684

Bhargava, V. (2013). Plus ca change, plue c'est la meme chose (the president's page). IEEE Communications Magazine, 51, 6. doi:10.1109/MCOM2013.6461172

Bisel, R. S., \& Arterburn, E. N. (2012). Making sense of organizational members' silence: A sensemaking-resource model. Communication Research Reports, 29, 217-226. doi:10.1080/08824096.2012.684985

Brown, W., \& May, D. (2012). Organizational change and development: The efficacy of transformational leadership training. Journal of Management Development, 31, 520-536. doi:10.1108/02621711211230830

Callahan, J. L. (2008). The four c's of emotion: A framework for managing emotions in organizations. Organizational Development Journal, 26, 33-39. Retrieved from http://www.odinstitute.org

Chang, J. C., Lu, D. B., Kung, S. F., \& Ueda. A. (2014, November). Theory and application of tacit knowledge transfer. Creative Education, 1733-1739. doi:10.4236./ce.2014.519193

Chang, J., Sy, T., \& Choi, J. (2012). Team emotional intelligence and performance: Interactive dynamics between leaders and members. Small Group Research, 43, 75-104. doi:10.1177/1046496411415692

Chaudhry, A. Q., \& Javed, H. (2012). Impact of transactional and laissez faire leadership styles on motivation. International Journal of Business and Social Science, 3, 258-264. Retrieved from http://www.ijbssnet.com

Cheng, T., Huang, G., Lee, C., \& Xiaopeng, R. (2012). Longitudinal effects of job insecurity on employee outcomes: The moderating role of emotional intelligence and the leader member exchange. Asia Pacific Journal of Management, 29, 709-728. doi:10.1007/s10490-010-9227-3

Cheung, M. F. Y., \& Wu, W. (2012). Leader-member exchange and employee work outcomes in Chinese firms: The mediating role of job satisfaction. Asia Pacific Business Review, 18, 6581. doi:10.1080/13602381.2010.535346

Cole, M. S., Bedeian, A. G., \& Bruch, H. (2011). Linking leader behavior and leadership consensus to team performance: Integrating direct consensus and dispersion models of group composition. The Leadership Quarterly, 22, 383-398. doi:10.1016/j.leaqua.2011.02.012

Colville, I., Brown, A. D., \& Pye, A. (2011). Simplexity: Sensemaking, organizing and storytelling for our time. Human Relations, 65, 5-15. doi:10.1177/0018726711425617 
Conroy, S. A., \& O'Leary-Kelly, A. M. (2014). Letting go and moving on: Work-related identity loss and recovery. Academy of Management Review, 39, 67-87. doi:10.5465/amr.2011.0396

Cote, S., Lopes, P. N., Salovey, P., \& Miners, C. T. H. (2010). Emotional intelligence and leadership emergence in small group. Leadership Quarterly, 21, 495-508. doi:10.1016/j.leaqua.2010.03.012

da Cruz, M. R. P., Nunes, A. J. S., \& Pinheiro, P. G. (2011). Fiedler's contingency theory: Practical application of the least preferred coworker (LPC) scale. IUP Journal of Organizational Behavior, 10, 7-26. Retrieved from http://www.iupindia.in

Dadhich, A., \& Bhal, K. T. (2008). Ethical leader behavior and leader-member exchange as predictors of subordinate behaviors. Vikalpa: The Journal for Decision Makers, 33, 15-25. Retrieved from http://www.vikalpa.com

Dennis, B. (2010, June). Ethical dilemmas in the field: The complex nature of doing education ethnography. Ethnography and Education, 5, 123-127. doi:10.1080/17457823.2010.493391

Denzin, N. K. (2008). The new paradigm dialogs and qualitative inquiry. International Journal of Qualitative Studies in Education, 21, 315-325. doi:1080/09518390802136995

Denzin, N. K. (2012). Triangulation 2.0. Journal of Mixed Methods Research, 6, 80-88. doi:10.1177?1558689812437186

Derue, D. S., Nahrgang, J. D., Wellman, N., \& Humphrey, S. E. (2011). Trait and behavioral theories of leadership: An integration and meta-analytic test of their relative validity. Personnel Psychology, 64, 7-52. doi:10.1111/j.1744-6570.2010.01201.x

de Wit, F. R. C., Greer, L. L., \& Jehn, K. A. (2011). The paradox of intragroup conflict: A metaanalysis. Journal of Applied Psychology, 97, 360-390. doi:10.1037/a0024844

Dibley, L. (2011). Analyzing narrative data using McCormack's lenses. Nurse Researcher, 18, 13-19. Retrieved from http://nurseresearcher.rcnpublishing.co.uk/news-andopinion/commentary/analysing-qualitative-data

Ding, X., Tian, K., Yang, C., \& Gong, S. (2012). Abusive supervision and LMX: Leaders' emotional intelligence as antecedent variable and trust as consequence variable. Chinese Management Studies, 6, 257-270. doi:10.1108/17506141211236695

Doody, O., Slevin, E., \& Taggart, L. (2013). Focus group interviews. Part 3: Analysis. British Journal of Nursing, 22, 266-269. Retrieved from http://www.internurse.com/cgibin/go.pl/library/article.cgi?uid=97512;article=BJN_22_5_266_269

Douglas, C. (2012). The moderating role of leader and follower sex dyads on the leadership behaviorleader effectiveness relationships. The Leadership Quarterly, 23, 163-175. doi:10.1016/j/leaqua.2011.11.013

Dulebohn, J. H., Bommer, W. H., Liden, R. C., Brouer, R. L., \& Ferris, G. R. (2012). A meta-analysis of antecedents and consequences of leader-member exchange: Integrating the past with an eye toward the future. Journal of Management, 38, 1715-1759. doi:10.1177/0149206311415280

Dunn, J. H. (2012). The decline of manufacturing in the United States and its impact on income inequality. Journal of Applied Business Research, 28, 995-1000. Retrieved from http://journals.cluteonline.com/index.php/JABR/article/view/7240

Edwards, G., \& Gill, R. (2012). Transformational leadership across hierarchical levels in UK manufacturing organizations. Leadership \& Organization Development Journal, 33, 25-50. doi:10.1108/01437731211193106 
Farh, C. C., \& Seo, T. (2012). Emotional intelligence, teamwork effectiveness, and job performance: The moderating role of job context. Journal of Applied Psychology, 97, 890-900. doi:10.1037/a0027377

Fisk, G. M., \& Friesen, J. P. (2012). Perceptions of leader emotion regulation and LMX as predictors of followers; job satisfaction and organizational citizenship behaviors. The Leadership Quarterly, 23, 1-12. doi:10.1016/j.leaqua.2011.11.001

Fusch, G. E. (2008, December). What happens when the ROI model does not fit? Performance Improvement Quarterly, 14, 60-76. doi:10.1111/j.1937-8327.2001.tb00230.x

Gil-Garcia, J. R. (2012). Towards a smart state? Inter-agency collaboration, information integration, and beyond. The International Journal of Government \& Democracy in the Information Age, 17, 269-280. Retrieved from http://www.iospress.nl/journal/information-polity/

Goldman, D. B., \& Wade, N. G. (2012). Comparison of forgiveness and anger-reduction group treatments: A randomized controlled trial. Psychotherapy Research, 22, 604-620. doi:10.1080/10503307.2012.692954.

Gordon, W. (2011). Behavioral economics and qualitative research-a marriage made in heaven? International Journal of Market Research, 53, 171-185. doi:10.2501/IJMR-53-2- 171-186

Green, M., DeCourville, N., \& Sadava, S. (2012). Positive affect, negative affect, stress, and social support mediators of the forgiveness-health relationship. Journal of Social Psychology, 152, 288-307. doi:10.1080/00224545.2011.603767

Guest, G., Bunce, A., \& Johnson, L. (2006). How many interviews are enough? An experiment with data saturation and variability. Field Methods, 18, 59-82. doi:10.1177/1525822X05279903

Hargis, M. B., Watt, J. D., \& Piotrowski, C., (2011). Developing leaders: Examining the role of transactional and transformational leadership across business contexts. Organization Development Journal, 29, 51-66. Retrieved from http://www.instituteod.com/

Harrell, E. (2011). Workplace violence, 1993-2009 (Special Report NCJ 233231). Bureau of Justice Statistics. Retrieved from http://www.bjs.gov/content/pub/pdf/wv09.pdf

Harris, K. J., Harvey, P., \& Kacmar, M. (2011). Abusive supervisory reactions to coworker relationship conflict. The Leadership Quarterly, 22, 1010-1023. doi:10.1016.j.leaqua.2011.07.020

Hodson, R. (2008). The ethnographic contribution to understanding co-worker relations. British Journal of Industrial Relations, 46, 169-192. doi:10.1111/j.1467-8543.2007.00670.x

Hoffman, B. J., Woehr, D. J., Maldagen-Youngjohn, R., \& Lyons, B. D. (2011). Great man or great myth? A quantitative review of the relationship between individual differences and leader effectiveness. Journal of Occupational and Organizational Psychology, 84, 347-381. doi:10.1348/096317909X485207

Humborstad, S. I. W., Nerstad, C. G. L., \& Dysvik, A. (2014). Empowering leadership, employee goal orientations and work performance: A competing hypothesis approach. Personnel Review, 43, 246-271. doi:10.1108/PR-01-2012-0008

Ivanova, M., \& Torkkli, L. (2013). Managerial sensemaking of interaction within business relationships: A cultural perspective. European Management Journal, 31, 717-727. doi:10.1016/j.emj.2013.07.007

Jackson, J. E. (1990). I am a fieldnote: Fieldnotes as a symbol of professional identity. In R. Sanjek (Ed.), Fieldnotes: The making of anthropology (pp. 3-33). Ithaca, NY: Cornell University Press. 
Jackson, E. M., \& Johnson, R. E. (2012). When opposites do (and do not) attract: Interplay of leader and follower self-identities and its consequences for leader-member exchange. The Leadership Quarterly, 23, 488-501. doi:10.1016/j.leaqua.2011.12.003

Jacobellis v. Ohio, 378 U.S. 184 (1964).

Judge, T. A., \& Piccolo, R. F. (2004). Transformational and transactional leadership: A meta-analytic test of their relative validity. Journal of Applied Psychology, 89, 755-768. doi:10.1037/00219010.89.5.755

Judge, T. A., Piccolo, R. F., \& Kosalka, T. (2009). The bright and dark sides of leader traits: A review and theoretical extension of the leader trait paradigm. The Leadership Quarterly, 20, 855875. doi:10.1016/j.leaqua.2009.09.004

Kacmar, K. M., Bachrach, D. G., Harris, K. J., \& Noble, D. (2012). Exploring the role of supervisor trust in the associations between multiple sources of relationship conflict and organizational citizenship behavior. The Leadership Quarterly, 23, 43-54. doi:10.1016/j.leaqua.2011.11.004

Kirby, D. (2011). "No one can whistle a symphony. It takes an orchestra to play it." Asian Social Science, 7, 36-44. Retrieved from http://www.ccsenet.org/journal/index.php/ass/article/view/9394

Klein, K. J., Knight, A. P., Ziegert, J. C., Lim, B. C., \& Saltz, J. L. (2011). When team members' values differ: The moderating role of team leadership. Organizational Behavior and Human Decision Processes, 114, 25-36. doi:10.1016/j.obhdp.2010.08.004

Kotlyar, I., Karakowsky, L., \& Ng, P. (2011). Leader behaviors, conflict and member commitment to team-generated decision. The Leadership Quarterly, 22, 666-679. doi:10.1016/j.leaqua.2011.05.007

Kraybill, R. S. (2011). Style matters: The Kraybill conflict style inventory. Retrieved from http://www.ConflictStyleMatters.com

Kuvaas, B., Buch, R., Dysvik, A., \& Harerem, T., (2012). Economic and social leader-member exchange relationships and follower performance. The Leadership Quarterly, 23, 745-764. doi:10.1016/j.leaqua.2011.12.013

Le Blanc, P. M., \& Gonzalez-Roma, V. (2012). A team level investigation of the relationship between leader-member exchange (LMX) differentiation and commitment and performance. The Leadership Quarterly, 23, 534-544. doi:10.1016/j/leaqua.2011.12.006

Lehmann-Willenbrock, N., Grohmann, A., \& Kauffeld, S. (2011). Task and relationship conflict at work: Construct validation of a German version of Jehn's intragroup conflict scale. European Journal of Psychological Assessment, 27, 171-178. doi:10.1027/1015-5759/a000064

Luthans, F., Rhee, S., Luthans, B. C., \& Avey, J. B. (2008). Impact of behavioral performance management in a Korean application. Organization Development Journal, 29, 427-443. doi:10.1108/01437730810887030

Manning, J., \& Kunkel, A. (2014). Making meaning of meaning-making research: Using qualitative research for studies of social and personal relationships. Journal of Social and Personal Relationships, 31, 433-441.doi:10.1177/0265407514525890

Marshall, C., \& Rossman, G. (2011). Designing qualitative research (2nd ed.). Thousand Oaks, CA: Sage.

Medler-Liraz, H., \& Kark, R. (2012). It takes three to tango: Leadership and hostility in the service encounter. The Leadership Quarterly, 23, 81-93. doi:10.1016/j.leaqua.2011.11.007 
Narasimhan, R., Krull, T. J., \& Nahm, A. (2012). Alternative relationships among integrative beliefs, time-based manufacturing and performance. International Journal of Operations \& Production Management, 32, 496-524. doi:10.1108/01443571211223112

Navakatikyan, M. A., \& Davidson, M. (2010). The dynamics of the law of effect: A comparison of models. Journal of the Experimental Analysis of Behavior, 93, 91-127. doi:10.1901/jeab.2010.93-91

Northouse, P. G. (2015). Leadership: Theory and practice (7th ed.). Thousand Oaks, CA: Sage.

Nowak, A., Deutsch, M., Bartkowski, W., \& Solomon, S. (2010). From crude law to civil relations: The dynamics and potential resolution of intractable conflict. Peace and Conflict: Journal of Peace Psychology, 16, 189-209. doi:10.1080/10781911003691617

Odumeru, J. A., \& Ifeanyi, G. O. (2013). Transformational vs transactional leadership theories: Evidence in literature. International Review of Management and Business Research, 2, 355361. Retrieved from http://irmbrjournal.com

Olaniran, B. A. (2010). Group communication and conflict management in an electronic medium. International Journal of Conflict Management, 21, 44-69. doi:10.1108/10444061011016623

Onwuegbuzie, A. J., Leech, N. L., \& Collins, K. M. T. (2010). Innovative data collection strategies in qualitative research. The Qualitative Report, 15, 696-726. Retrieved from http://www.nova.edu/ssss/QR/QR15-3/

Pelletier, K. L. (2011). Perceptions of and reactions to leader toxicity: Do leader-follower relationships and identification with victim matter? The Leadership Quarterly, 23, 412-424. doi:10.1016/j.leaqua.2011.09.011

Prilipko, E. V., Antelo, A., \& Henderson, R. L. (2011). Rainbow of follower's attributes in a leadership process. International Journal of Management \& Information Systems, 15, 79-94. Retrieved from http://journals.cluteonline.com/index.php/IJMIS/article/view/4157

Rockstuhl, T., Dulebohn, J. H., Ang, S., \& Shore, L. M. (2012). Leader-member exchange (LMX) and culture: A meta-analysis of correlates of LMX across 23 countries. Journal of Applied Psychology, 97, 1097-1130. doi:10.1037/a0029978

Rowe, M. (1997). Dispute resolution in the nonunion environment: An evolution toward integrated systems for conflict management. In S. Gleason (Ed.), Workplace dispute resolution, (pp. 79106). East Lansing, MI: Michigan State University Press.

Rubin, H. J., \& Rubin, I. S. (2012). Qualitative interviewing: The art of hearing data (3rd ed.). Thousand Oaks, CA: Sage.

Rupprecht, E. A., Waldrop, J. S., \& Grawitch, M. J. (2013). Initial validation of a new measure of leadership. Consulting Psychology Journal: Practice and Research, 65, 128-148. doi:10.1037/a0033127

Sabir, M., Sohail, A., \& Khan, M. (2011). Impact of leadership style on organization commitment: In a mediating role of employee value. Journal of Economics \& Behavioral Studies, 3, 145-152. Retrieved from http://www.ifrnd.org/journals_jebs.htm

Sadeghi, A., \& Pihie, Z. (2012). Transformational leadership and its predictive effects on leadership effectiveness. International Journal of Business \& Social Science, 3, 186-197. Retrieved from http://www.ijbssnet.com

Sangasubana, N. (2011). How to conduct ethnographic research. The Qualitative Report, 16, 567573. Retrieved from http://www.nova.edu/ssss/QR 
Shore, T. H., \& Strauss, J. (2012). Effects of pay and productivity comparisons in the workplace on employee attitudes: An experimental investigation. International Journal of Management, 29, 677-686. Retrieved from http://www.internationaljournalofmanagement.co.uk/

Spector, P. E. (2011). The relationship of personality to counterproductive work behavior (CWB): An integration of perspectives. Human Resource Management Review, 21, 342-352. doi:10.1016/j.jrmr.2010.10.002

Streb, C. K., \& Gellert, F. J. (2011). What do we know about managing aging teams? Lessons learned from the automotive shop floor. Organizational Dynamics, 40, 144-150. doi:10.1016/j.orgdyn.2011.01.009

Tabassi, A. A., \& Bahar, A. H. A. (2010). Towards assessing the leadership style and quality of transformational leadership. Journal of Technology Management in China, 5, 245-258. doi:10.1108/17468771011086256

Thomas, K. W., Thomas, G. F., \& Schaubhut, N. (2008). Conflict styles of men and women at six organizational levels. International Journal of Conflict Management, 19, 148-166. doi:10.1108/10444060810856085

Thorndike, E. L. (1898). Animal intelligence: An experimental study of the associative processes in animals. The Psychological Review: Monograph Supplements, 2, i-109. doi:10.1037/h0092987

Thurlow, A., \& Mills, J. H. (2009). Change, talk and sensemaking. Journal of Organizational Change Management, 22, 459-579. doi:10.1108/09534810910983442

Trudel, J., \& Reio, T. G. (2011). Managing workplace incivility: The role of conflict management styles: Antecedent or antidote? Human Resource Development Quarterly, 22, 395-423. doi:10.1002/hrdq.20081

Voegtlin, C., Patzer, M., \& Scherer, A. (2012). Responsible leadership in global business: A new approach to leadership and its multi-level outcomes. Journal of Business Ethics, 105, 1-16. doi:10.1007/s10551-011-0952-4

Volmer, J., Spurk, D., \& Niessen, C. (2011). Leader-member exchange (LMX), job autonomy, and creative work involvement. The Leadership Quarterly, 23, 456-465. doi:10.1016/j.leaqua.2011.10.005

Walker, J. L. (2012). The use of saturation in qualitative research. Canadian Journal of Cardiovascular Nursing, 22, 37-46. Retrieved from http://www.cccn.ca

Walumbwa, F. O., Peterson, S. J., Avolio, B. J., \& Hartnell, C. A. (2010). An investigation of the relationships among leader and follower psychological capital, service climate, and job performance. Personnel Psychology, 63, 937-963. doi:10.1111/j.1744-6570.2010.01193.x

Weick, K. E. (2011). Organized sensemaking: A commentary on processes of interpretive work. Human Relations, 65, 141-153. doi:10.1177/0018726711424235

Williams, F. (2011). Interpersonal conflict: The importance of clarifying manifest conflict behavior. International Journal of Business, Humanities \& Technology, 1, 148-160. Retrieved from http://www.ijbhtnet.com/

Yin, R. K. (2015). Case study research: Designs and methods (5th ed.). Thousand Oaks, CA: Sage.

Yuan, W. (2010). Conflict management among American and Chinese employees in multinational organizations in China. Cross Cultural Management: An International Journal, 17, 299-311. doi:10.1108/13527601011068388 
Zhu, W., Sosik, J. J., Riggio, R. E., \& Yang, B. (2012). Relationships between transformational and active transactional leadership and followers' organizational identification: The role of psychological empowerment. Journal of Behavioral and Applied Management, 13, 186-212. Retrieved from http://www.ibam.com/pubs/jbam

Zimmerman, A. (2011). Interpersonal relationships in transnational, virtual teams: Towards a configurational perspective. International Journal of Management Reviews, 13, 59-78. doi:10.1111/j.1468-2370.2010.00284.x

The International Journal of Applied Management and Technology (IJAMT), sponsored by Walden University's School of Management, is a peer-reviewed, online journal that addresses contemporary national and international issues related to management and technology. The objectives of the IJAMT are to: (a) encourage collaborative and multi-disciplinary examinations of important issues in business and technology management, and (B) engage scholars and scholar-practitioners in a dynamic and important dialogue.

Walden University Publishing: http://www.publishing.waldenu.edu 